\title{
Geochemical behaviour of rare earths in Vitis vinifera grafted onto different rootstocks and growing on several soils
}

\author{
P. Censi ${ }^{\text {a, } *}$, F. Saiano ${ }^{\text {b }}$, A. Pisciotta ${ }^{\text {b }}$, N. Tuzzolino ${ }^{\text {a }}$ \\ a DISTEM, University of Palermo, Via Archirafi, 22-90123 Palermo, Italy \\ b SAF Department, University of Palermo, Viale delle Scienze, 13-90128 Palermo, Italy
}

\section{H I G H L I G H T S}

- REE behaviour is driven by scavenging onto authigenic solids or membranes in roots.

- REE behaviour is driven by dissolved complexation in aerial plant parts.

- Positive Eu anomalies are a consequence of the REE translocation by xylem fluids.

- Significant REE tetrad effects are observed in Vitis vinifera plants.

\section{A R T I C L E I N F O}

\section{Article history:}

Received 23 July 2013

Received in revised form 15 October 2013

Accepted 16 December 2013

Available online $\mathrm{xxxx}$

\section{Keywords:}

Vitis vinifera

Rare Earth Elements

Geochemical behaviour

Soil

\begin{abstract}
A B S T R A C T
The geochemical behaviour of lanthanides and yttrium (Rare Earth Elements, REEs) has been investigated mainly in geological systems where these elements represent the best proxies of processes involving the occurrence of an interface between different media. This behaviour is assessed according to features recorded in sequences of REE concentrations along the REE series normalised with respect to a reference material. In this study, the geochemical behaviour of REE was investigated in different parts of Vitis vinifera specimens grown off-soil, on soils of different nature and grafted onto several rootstocks in order to evaluate effects induced by these changes. The results indicated that roots are the plant organs where REEs are preferentially concentrated, in particular elements from Sm to Ho (middle REE, MREE) whereas Eu enrichments occur in aerial parts. The geochemical behaviour of REE suggests that MREE enrichments in roots are due to preferential MREE interactions with biological membranes or to surface complexation with newly formed phosphates. Eu-positive anomalies suggest that $\mathrm{Eu}^{3+}$ can form stable organic complexes in place of $\mathrm{Ca}^{2+}$ in several biological processes in xylem fluids. The possibility that Eu mobility in these fluids can be enhanced by its reductive speciation as $\mathrm{Eu}^{2+}$ cannot be ruled out.

The assessment of the geochemical behaviour of REE according to the theory of the Tetrad Effect carried out confirms that REEs coming from soil are scavenged onto root tissues or mineral surfaces whereas their behaviour in aerial parts of $V$. vinifera is driven by dissolved complexation.
\end{abstract}

(c) 2013 Elsevier B.V. All rights reserved.

\section{Introduction}

Vitis vinifera is a plant cultivated since ancient times, and this is related to the importance that this species has for people, both as food and for cultural reasons. Products derived from $V$. vinifera are so widely used that it is difficult to identify cultures that do not use them extensively. Therefore, recognition of the capacity of $V$. vinifera to extract minor and trace components from the growth substrate, as well as the fate of these elements during processes occurring in the rhizosphere and their transport through the xylem towards the aerial

\footnotetext{
* Corresponding author. Tel.: + 39 09123861639; fax: + 3909123860835 E-mail address: paolo.censi@unipa.it (P. Censi).
}

parts of plants, represents an interesting research focus. Only a limited number of studies have been carried out on this topic (Bavaresco, 1997; Bertoldi et al., 2011; Chopin et al., 2008; Ortiz-Villajos et al., 2012; Rodushkin et al., 1999) and these studies were mainly focused on the accumulation of toxic species in Vitis berries (Bertoldi et al., 2013). Only a few case-studies have been carried out investigating lanthanides and yttrium (namely Rare Earth Elements, REEs) distributions in V. vinifera (Bertoldi et al., 2009, 2011), but these data were not treated according to an approach highlighting the geochemical behaviour of these elements in the $V$. vinifera/soil system. On the contrary, REE concentrations are simply discussed according to a "classical" approach without any consideration of their particular chemical behaviours during multiple processes occurring in biological systems. This choice reduced the ability of studies carried out until 
now to obtain information about processes involving REE during the growth of $V$. vinifera that can be enhanced by the geochemical treatment of REE data through the use of normalised REE concentrations and the derivate characteristics as are detailed below.

This current research allows these limitations to be overcome through a detailed analysis of REE distributions, studying the "geochemical behaviour" of REE behaviour during the growth of $V$. vinifera with both on-soil and off-soil procedures. Moreover, due to the sensitivity of $V$. vinifera towards phylloxera, cultivated $V$. vinifera are usually inserted onto different rootstock species, so that effects related to different rootstocks on REE behaviour in different parts of Vitis have to be evaluated during studies of REE behaviour in grapevines. REEs have been studied due to their progressively increasing exploitation in industrial practices, leading to their potential accumulation as pollutants. Particularly in China, REEs have often been added as fertiliser during agricultural activities to increase the growth rates of several vegetal species, which stimulate the production of secondary metabolites in several plants (d'Aquino et al., 2009; Hu et al., 2004; Liang et al., 2005; Xin et al., 2013), whereas their affinity for phosphates can lead to their enrichment in fertilisers worldwide.

Furthermore, REE's characteristics allow them to represent probably the best geochemical tracer of processes involving the occurrence of an interface between media with different chemical-physical characteristics. This aspect makes REE the best choice to investigate processes occurring to trace elements during their migration from soil to plant and its fruits (Liang et al., 2008; Tyler, 2004).

Although interface studies related to REE behaviour have focused on rock/water interactions (Bau and Dulski, 1996; Michard et al., 1989; Möller and Giese, 1997; Möller et al., 2003 and references therein), these have recently been extended towards biological systems, biofilms and bacterial colonies (Davranche et al., 2004, 2005, 2008, Takahashi et al., 2002, 2005, 2007). The binding between biological surfaces and dissolved REE occurs through O-donor groups that join into the REE coordination sphere forming surface complexes. Elements along the REE series are differently involved in this process depending on the involved binding groups on the biological surface and the physicalchemical conditions occurring in the system (Takahashi et al., 2010). Recently, Takahashi et al. (2010) showed that the REE complexation onto biological surfaces occurs by means of carboxylate and/or polyphosphate binding groups. The former ligands show larger affinity towards heavier REE, from Ho to Lu (HREE) whereas the latter O-donor groups preferentially fractionate middle REE, from Sm to Dy (MREE). However, the REE behaviour represents a suitable geochemical proxy of interface processes even if biological substrata are involved (Moriwaki et al., 2013). The REE behaviour in the $V$. vinifera/soil system can represent a very promising application of the analysis of distributions of these elements among different media, from the inorganic soil interface to the coexisting fluid phase and hence to the biological medium in the plant.

\section{Geochemical characters of REE}

Lanthanides are a group of 14 elements from ${ }_{58} \mathrm{Ce}$ to ${ }_{71} \mathrm{Lu}$ produced by progressive filling of the $4 f$ orbital. Their chemical characters are a consequence of two main aspects:

- Since $4 f$ electrons occupy an inner position closer to the nucleus, elements from ${ }_{58} \mathrm{Ce}$ to ${ }_{71} \mathrm{Lu}$ have the same outer electronic configuration, corresponding to [Xe]6s $s_{2} 5 d_{1}$ (Shannon, 1976). $4 f$ electrons are not involved in chemical bonds. ${ }_{57} \mathrm{La}$ is also associated with lanthanides having the same external electronic configuration.

- The progressive decrease of ionic dimensions caused by the poor shielding of the 4 electrons (lanthanide contractions) produces slight changes of the $\mathrm{S}^{3+} / \mathrm{r}$ ratio that influence lanthanide reactivity, especially in aqueous systems. Yttrium is also usually associated with lanthanides having the same $3+$ ionic charge and radius intermediate between $\mathrm{Ho}$ and $\mathrm{Er}$ (Shannon, 1976).
Lanthanides, La and Y are usually associated to form the Rare Earths' group (REE). REEs have a typical 3 + oxidative state. Only Ce and Eu can occur as $\mathrm{Ce}^{4+}$ and $\mathrm{Eu}^{2+}$ under selected environmental oxidising or reducing conditions, respectively.

From a geochemical point of view, REEs behave similarly but not identically during CHarge and RAdius Controlled natural processes (CHARAC) such as those allowing magma crystallisations (Bau, 1996). The limited observed differences are related to the wide range of REE coordination numbers ranging from 6 to 12 leading to their different "geochemical compatibility" towards crystal lattices of minerals. Similar slight differences among REEs also remain during aqueous reactions such as dissolved or surface complexation (adsorption). These differences are more evident between $\mathrm{Y}$ and Ho and allow their decoupling due to the different electronic configurations. The different REE behaviours between CHARAC and non-CHARAC (aqueous) processes and then between crystalline solids and aqueous fluids (Bau, 1996) make REE probably among the best geochemical tracers for studying solid/liquid interfaces.

Since in both aqueous systems and during crystallisation processes, the characteristics of REE change continuously with ionic radius along the series, the geochemical behaviour of REE can be evidenced through the shape of the sequence of REE normalised concentrations assessed by:

$$
\left[\operatorname{REE}_{\mathrm{i}}\right]_{\mathrm{n}}=\frac{\left[\mathrm{REE}_{\mathrm{i}}\right]_{\text {sample }}}{\left[\mathrm{REE}_{\mathrm{i}}\right]_{\text {reference }}}
$$

(Taylor and McLennan, 1988) where the subscript " $n$ " refers to the normalised concentration of a given sample with respect to a material taken as reference. By studying enrichments or depletions of single elements along the series, usually named "anomalies", the evaluation of "geochemical behaviour" of REE is carried out. These anomalies can be assessed according to the equation:

$$
\frac{[\mathrm{REE}]_{\mathrm{i}}}{[\mathrm{REE}]_{\mathrm{i}} *}=\frac{2[\mathrm{REE}]_{\mathrm{i}}}{\left\{[\mathrm{REE}]_{\mathrm{i}+1}[\mathrm{REE}]_{\mathrm{i}-1}\right\}}
$$

where the subscript "i" indicates every element along the REE series whereas " $(\mathrm{i}-1)$ " and " $(\mathrm{i}+1)$ " are its immediate neighbour before and after within the series (Alibo and Nozaki, 1999). Features of normalised-REE patterns can also be evaluated considering enrichments or depletions of groups of REE subdivided into light REE, from La to Sm (LREE), middle REE, from Eu to Dy or Ho (MREE) and heavier REE, from $\mathrm{Ho}$ or $\mathrm{Er}$ and $\mathrm{Lu}$ (HREE) according to their atomic weight. Moreover, the sequence of the distribution coefficient values $\left(\mathrm{K}_{\mathrm{d}}\right)$, calculated as reported in Eq. (3), between REE concentrations is measured in two interfaced substances, 1 and 2:

$\mathrm{K}_{\mathrm{d}}=\frac{[\mathrm{REE}]_{1}}{[\mathrm{REE}]_{2}}$

and can be split into four different intervals, La-Nd, Pm-Gd, Gd-Ho and Er-Lu, called tetrads. They are referred to as the first $\left(t_{1}\right)$, second $\left(t_{2}\right)$, third $\left(t_{3}\right)$ and fourth tetrads $\left(t_{4}\right)$, respectively. Peppard et al. (1969) suggested that this effect (thereafter called the "Tetrad Effect") could be related to the progressive filling of the $4 f$ orbital. The shape of tetrad effects has been defined as W-type or M-type if the splitting produces upward convex or downward convex features, respectively. Similar features have also been observed during several geochemical and biogeochemical processes (Bau, 1999; Irber, 1999; Kawabe, 1992; Masuda and Ikeuchi, 1979; Masuda et al., 1987; Monecke et al., 2002) and their occurrences were attributed to REE complexation with an inner-sphere mechanism either in a dissolved pool or onto surfaces. This suggestion makes the amplitude of tetrad effects a geochemical proxy to discriminate between strong, inner-sphere coordination bonds and simple adsorption or outer-sphere coordination processes. The amplitudes of 

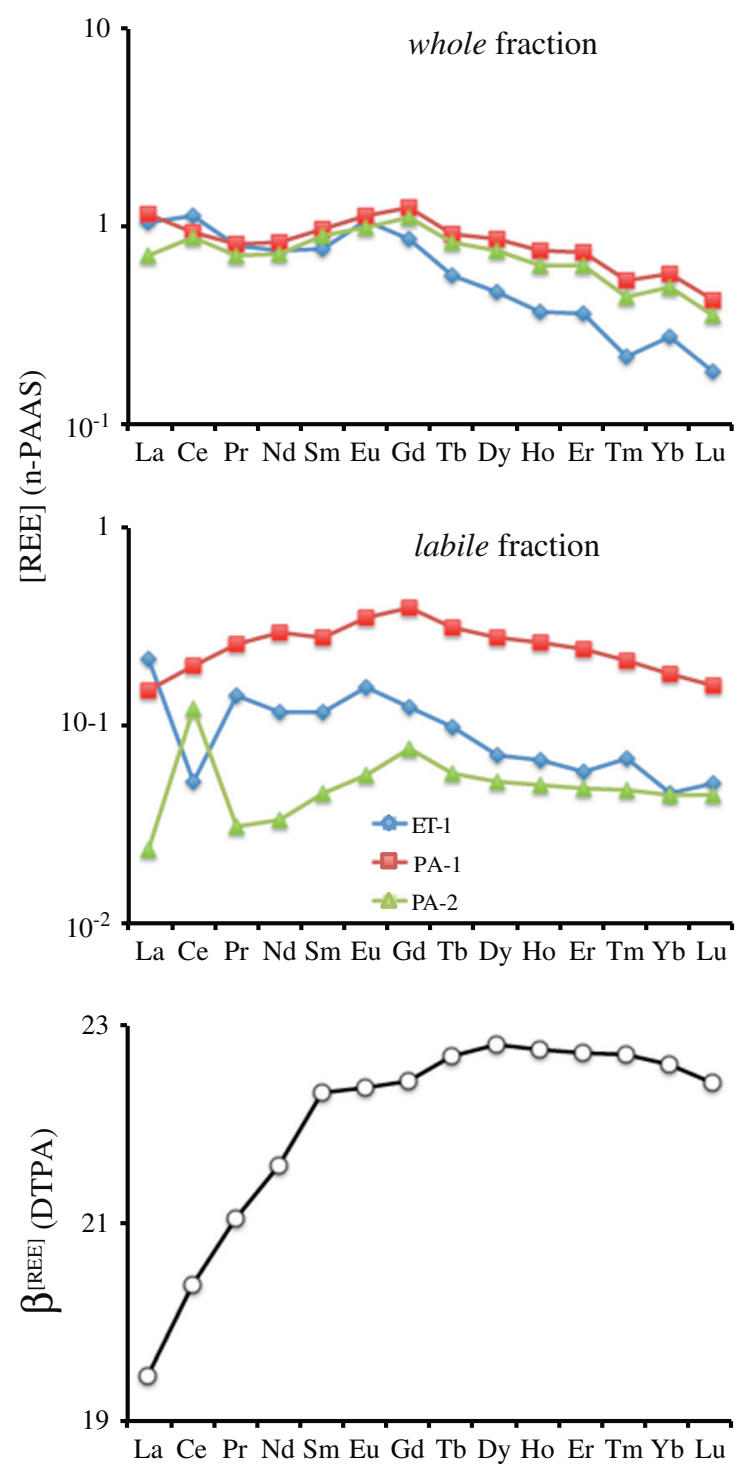

Fig. 1. Shale-normalised REE patterns of investigated soils and extracted fractions compared with features of stability constants for REE-DTPA complexes (Byrne and Li, 1995).

tetrad effects can be evaluated according to Eq. (4) for the third and fourth tetrads:

$\mathrm{t}_{3}=\sqrt{\frac{[\mathrm{Tb}]_{\mathrm{n}} *[\mathrm{Dy}]_{\mathrm{n}}}{[\mathrm{Gd}]_{\mathrm{n}} *[\mathrm{Ho}]_{\mathrm{n}}}}$
$\mathrm{t}_{4}=\sqrt{\frac{[\mathrm{Tm}]_{\mathrm{n}} *[\mathrm{Yb}]_{\mathrm{n}}}{[\mathrm{Er}]_{\mathrm{n}} *[\mathrm{Lu}]_{\mathrm{n}}}}$

and can represent tetrad curvatures due to the splitting of normalisedREE patterns (Irber, 1999). This curvature is significant if $t_{i}<0.95$ and $t_{i}>1.05$, leading to $W$ - or M-type tetrad effects, respectively.

\section{Materials and methods}

\subsection{Soils}

REE distributions in the $V$. vinifera/soil system were investigated taking into account soils coming from different parent rocks in order to evaluate effects related to the mineralogical composition of substrates that represent the source of nutrients and trace elements for the plant. Three different soils from volcanic and sedimentary parent materials were considered. These soils were collected near Viagrande, close to Catania, (ET-1 soil) on the slope of Mt. Etna $\left(37^{\circ} 37^{\prime} 19.77^{\prime \prime} \mathrm{N}-\right.$ $15^{\circ} 5^{\prime} 41.69^{\prime \prime} \mathrm{E}, 1200 \mathrm{~m}$ sea level), in the San Giuseppe Iato area, (PA-1 soil) close to Palermo $\left(37^{\circ} 59^{\prime} 2.54^{\prime \prime} \mathrm{N}-13^{\circ} 11^{\prime} 44.13^{\prime \prime}\right.$ E, $610 \mathrm{~m}$ sea level) and in the coastal plain of Palermo $\left(38^{\circ} 06^{\prime} 23.14^{\prime \prime} \mathrm{N}-13^{\circ} 20^{\prime} 57.60^{\prime \prime} \mathrm{E}\right.$, $145 \mathrm{~m}$ sea level) (PA-2 soil). ET-1 is a soil formed from basaltic parent materials, PA-1 soil has a carbonatic-marly-clay precursor and PA-2 is formed from a calcarenitic parent rock.

With each investigated soil, a selective extraction of the bioavailable fraction (hereafter defined labile fraction) was carried out by treatment with DTPA at pH 5 (Ehlers and Luthy, 2003; Ehlken and Kirchner, 2002; Feng et al., 2005) to simulate as accurately as possible the natural capability of the grapevine rhizosphere to extract REE from the soil. Other than this labile fraction, a pseudo total soil $\mathrm{HNO}_{3}$ and $\mathrm{H}_{2} \mathrm{O}_{2}$ soluble fraction was also analysed and is hereafter defined as the whole fraction in order to evaluate the REE contents in carbonates, sulphates, oxides and less labile phases but to avoid REE release from silicates. This selection allowed us to evaluate how many more resistant minerals could be involved in REE delivery to $V$. vinifera.

The whole soil fraction was obtained by dissolving $250 \mathrm{mg}$ of the previously dried soil with $3 \mathrm{ml}$ of ultrapure $\mathrm{HNO}_{3}(65 \% \mathrm{v} / \mathrm{v})$ and $1.5 \mathrm{ml}$ of ultrapure $\mathrm{H}_{2} \mathrm{O}_{2}(30 \% \mathrm{v} / \mathrm{v})$ in a PFA ${ }^{\mathrm{TM}}$ vessel in a mineralising MicroWave-assisted oven (MARS 5 Xpress $^{\mathrm{TM}}$, CEM Corporation). The obtained solution was filtered and brought to $10 \mathrm{ml}$. Before the analyses, the solution was further diluted 100 times. Each sample was determined in triplicate. The labile fraction was extracted by reacting $10 \mathrm{~g}$ of previously dried soil using $20 \mathrm{ml}$ of $5 \mathrm{mM}$ DTPA solution at $\mathrm{pH}$ 5. The obtained suspension was stirred for $24 \mathrm{~h}$ at $25^{\circ} \mathrm{C}$, filtered with Millipore ${ }^{\mathrm{TM}}$ membranes $(0.45-\mu \mathrm{m}$ membrane filter) and diluted 50 times prior to the analyses. This procedure was also repeated three times.

\subsection{V. vinifera}

Due to the sensitivity of $V$. vinifera towards the phylloxera contagion infesting their root system, $V$. vinifera growth usually results from grafting a specific cultivar onto a rootstock. Therefore, three different rootstocks were selected in order to investigate the biogeochemical behaviour of REE during the growth of $V$. vinifera. The selected items were chosen among those more widely exploited in Sicily as a consequence of their adaptability to climatic conditions occurring there. These rootstocks are hybrids produced from American varieties Vitis rupestris, Vitis riparia and Vitis berlandieri, known as 1103 Paulsen, 779 Paulsen and 140 Ruggeri, respectively. Each rootstock was planted on all three selected soils in the greenhouse of the Agricultural and Forest Sciences (SAF) Department (University of Palermo) in order to recognise joint effects of rootstocks and soils on the biogeochemical behaviour of REE. The 1103 Paulsen was driven onto an artificial substrate formed by silicate gravel and peat in order to investigate what changes could be induced in the biogeochemical behaviour of REE if these elements were mainly released from the organic fraction of the substrate, considering that the gravel was not involved in REE leaching.

The relationship occurring between REE chemistry in soil and berries was investigated by Moscato d'Asti and Sauvignon blanc berries driven onto the investigated soils, the rootstock fructifications being only minimally significant without any graft.

Digestions of vegetal tissues were carried out after the separation of different plant organs by cutting. Each plant portion was washed, weighed $( \pm 0.0001 \mathrm{~g})$, dried at $105{ }^{\circ} \mathrm{C}$ to attain a constant weight, ground in an agate mortar, completely homogenised and stored in a PE vessel. Then, $250 \mathrm{mg}$ of each sample was put in a Teflon PFA ${ }^{\mathrm{TM}}$ vessel, $4.5 \mathrm{ml}$ of $2: 1 \mathrm{v} / \mathrm{v}$ mixture of $\mathrm{HNO}_{3}(65 \% \mathrm{w} / \mathrm{w}): \mathrm{H}_{2} \mathrm{O}_{2}(30 \% \mathrm{w} / \mathrm{w})$ was added, the container sealed and put in the microwave-assisted oven.

Analyses were carried out in a quadrupole ICP-MS (Agilent 7500 mass spectrometer). Extensive evaluations of spectral and isobaric interferences in REE determinations were carried out according to 


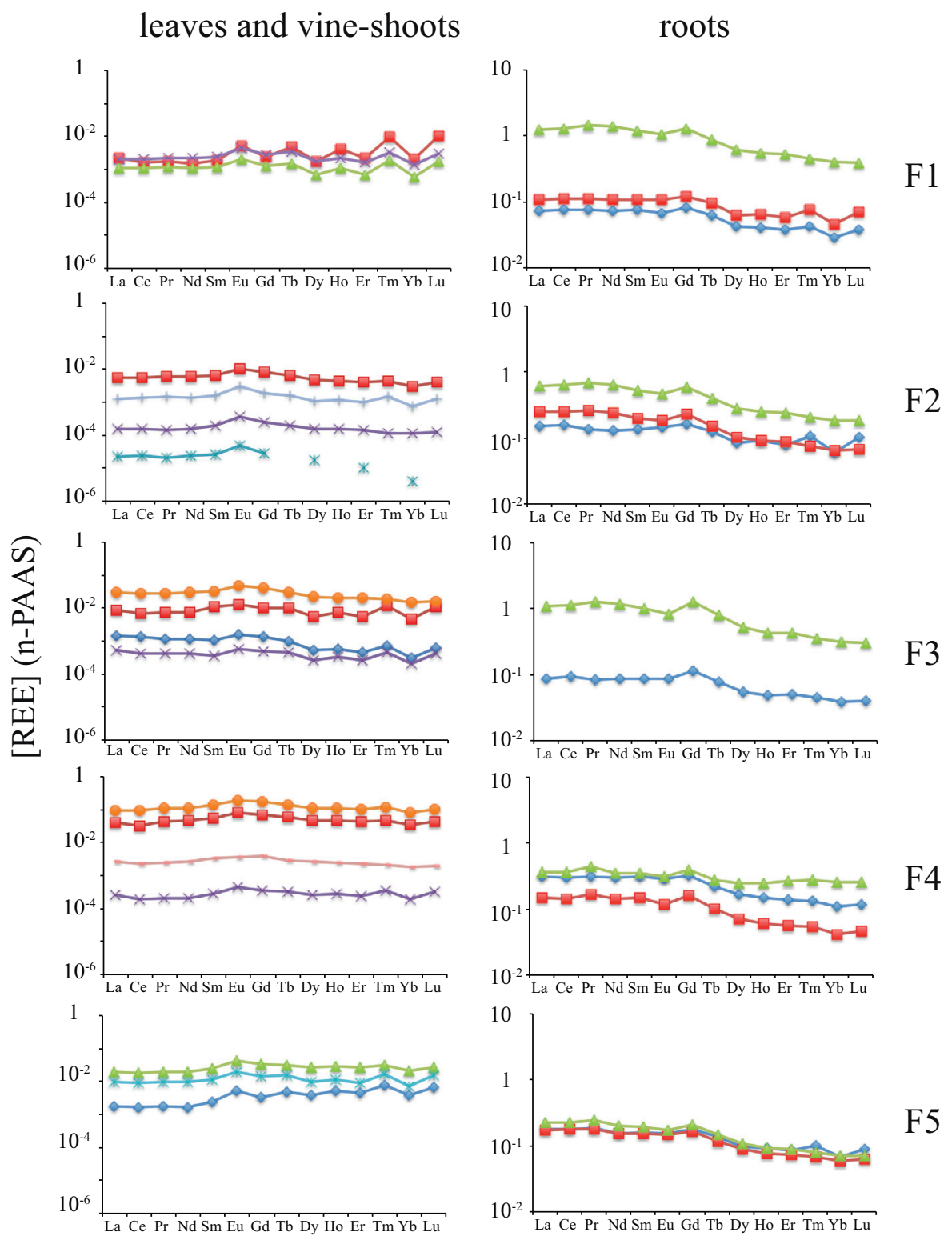

Fig. 2. Shale-normalised REE patterns measured in root and aerial parts of plants growing under off-soil conditions during different growing stages (F1-F5).

Darrah et al. (2009) and Raso et al. (2013). The precision and accuracy of the procedures were evaluated by analysing a INCT-OBTL- 5 standard reference material (tobacco leaves from the Poland Institute of Nuclear Chemistry and Technology, see Samczynski et al., 2012). The larger percentage error with respect to certified REE concentrations is found during the Ce determination $(-10.1 \%)$ whereas less error occurs for Er analyses (1.2\%). The largest percentage error is made in Lu determinations but the reported values are only suggested (Samczynski et al., 2012) and analysed mean Lu contents in measured standard tobacco leaves fall inside the range of the reported intercalibration standard analyses. All the analyses of standard reference material are reported in Supplementary information 1.

\section{Results}

\subsection{Soils}

REE distributions in the investigated soils are reported in Supplementary information 2. REE contents in the whole fraction ranged from 1239.94 to $1486.55 \mu \mathrm{mol} 1^{-1}$ in PA- 2 and PA- 1 soils, respectively. These results suggest a larger REE delivery from arenaceous and marly parent materials of PA-1 soil with respect to calcarenitic parent materials of PA-2 soil. REE contents from the labile fractions ranged from 117.65 to $415.43 \mu \mathrm{mol} \mathrm{l}^{-1}$ in PA-2 and PA-1 soils, giving us the indication of a REE richer labile fraction in PA-2 soil, probably associated with $\mathrm{Mn}-\mathrm{Fe}$ oxyhydroxides and carbonates, with respect to calcarenitic PA-1 soil where only carbonates occur. Analogous evidence from the labile fractions indicated that its incidence in whole soil is rather different among the investigated soils, varying from $9 \%$ to $27 \%$ in the PA-2 and PA-1 soils, respectively. REE patterns were calculated by normalising the measured concentrations to Post Archean Australian Shale (PAAS) as a reference (Taylor and McLennan, 1995). Their features are reported in Fig. 1. REE patterns in labile soil fractions are characterised by a progressive decrease in shale-normalised REE concentrations along the series, by Ce anomalies, positive in PA-2 and negative in ET-1 soils, and by MREE enrichment centred on Eu or Gd in PA-1.

By contrast, whole soil fractions showed very different features. Sedimentary PA soils are similar, with REE distributions symmetrical along the series, with MREE enriched with respect to LREE and HREE. On the other hand, ET-1 soil showed similar features to PA soils from La to Eu and a normalised REE path decreasing from Gd to Lu. The larger LREE partitioning in ET-1 is consistent with the more incompatible 
PA-2 PA-1 ET-1
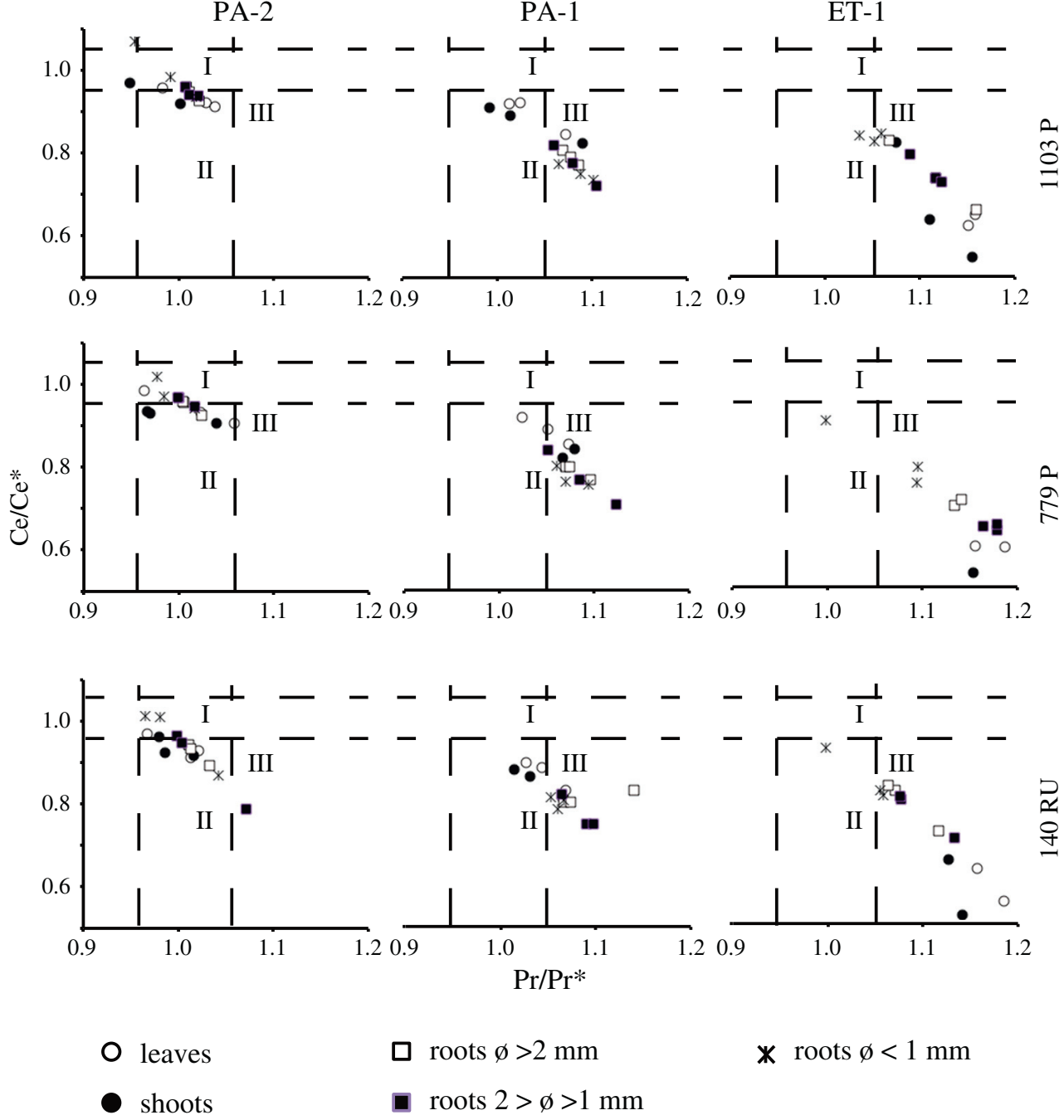
$\square \operatorname{roots} \emptyset>2 \mathrm{~mm}$
roots $2>\emptyset>1 \mathrm{~mm}$

* $\operatorname{roots} \varnothing<1 \mathrm{~mm}$

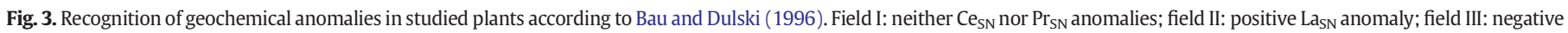
$\mathrm{Ce}_{\mathrm{SN}}$ anomaly.

nature of these elements that usually allows them to fractionate into intraplate basic magmatic products such as those associated with the Mt. Etna volcanism (Busà et al. 2002; Viccaro et al., 2006) and can be observed both in the labile and whole fractions. By contrast, the MREE fractionation in PA soils could be related to their larger Fe-oxyhydroxide and carbonate contents (Bau, 1999; Haley et al., 2004).

Comparing the REE patterns of labile fractions with the sequence of stability constants for REE-DTPA complexes $\beta_{\mathrm{DTPA}}^{\text {(REE) }}$ (Fig. 1), the observed differences suggest that REE contents in labile fractions are related to dissolution of the Fe-oxyhydroxide component rather than related to the REE fractionation induced by DTPA complexation.

The $\mathrm{Y} / \mathrm{Ho}$ molar ratio values were superchondritic $\left(\mathrm{Y} / \mathrm{Ho}_{(\text {molar })}>52\right)$ in PA soils and chondritic in ET-1 soil, especially in labile soil fractions (Supplementary material 2). This evidence is consistent with the larger Lewis acid softness of yttrium with respect to Ho (Cotton, 2006) leading to its larger mobility during interactions between soil and the rhizosphere. Higher $\mathrm{Y} / \mathrm{Ho}$ values recognised in the labile soil fraction also agree with Y removal from the surface of clay minerals where it is preferentially retained with respect to Ho (Takahashi et al., 2004).

\subsection{Plants}

\subsubsection{Off-soil growth}

The off-soil development of $V$. vinifera plants (Moscato d'Asti variety grafted onto 1103 P rootstock) was considered during five growth stages followed for about 50 days. As reported in Supplementary information 3, the obtained values show that roots preferentially concentrate the largest REE contents, especially in fine roots during the first stage. Following this, REE contents in roots progressively decrease, suggesting trace element migration towards the aerial portions of the plants. This trend is especially enhanced during the third stage. During these stages, the Y/Ho (molar) ratio changes from values slightly higher than the "crustal" signature (close to 52; Bau, 1996) towards lower values from the roots to aerial portions, suggesting that Ho is preferentially mobilised with respect to Y during physiological processes. This evidence is in agreement with the progressive increasing stability of several organic-REE complexes along the series (Schijf and Byrne, 2001).

Shale-normalised REE patterns of these plants are characterised by LREE enrichments in root samples, especially in the finest parts, whereas the aerial parts show MREE and HREE enrichments (Fig. 2). These features are consistent with the above-mentioned behaviour of the $\mathrm{Y} / \mathrm{Ho}$ ratio and corroborate the hypothesis of increasing REE mobility with atomic number, characteristic of several organic-REE complexes (Sonke and Salters, 2006; Yamamoto et al., 2010). In these samples, a progressive growth in the Eu anomaly is observed, ranging from $\mathrm{Eu} / \mathrm{Eu}^{*}<1$ in roots to $\mathrm{Eu} / \mathrm{Eu}^{*} \geq 2$ in aerial parts. This evidence suggests that Eu is preferentially mobilised from roots to aerial parts and is bound in biological tissues therein, probably as a consequence of its similarity with respect to $\mathrm{Ca}^{2+}$ and a related involvement in biological processes (Yang and Sachs, 1989). Different features observed among REE patterns during the early 
$1103 \mathrm{P}$

leaves and vine-shoots
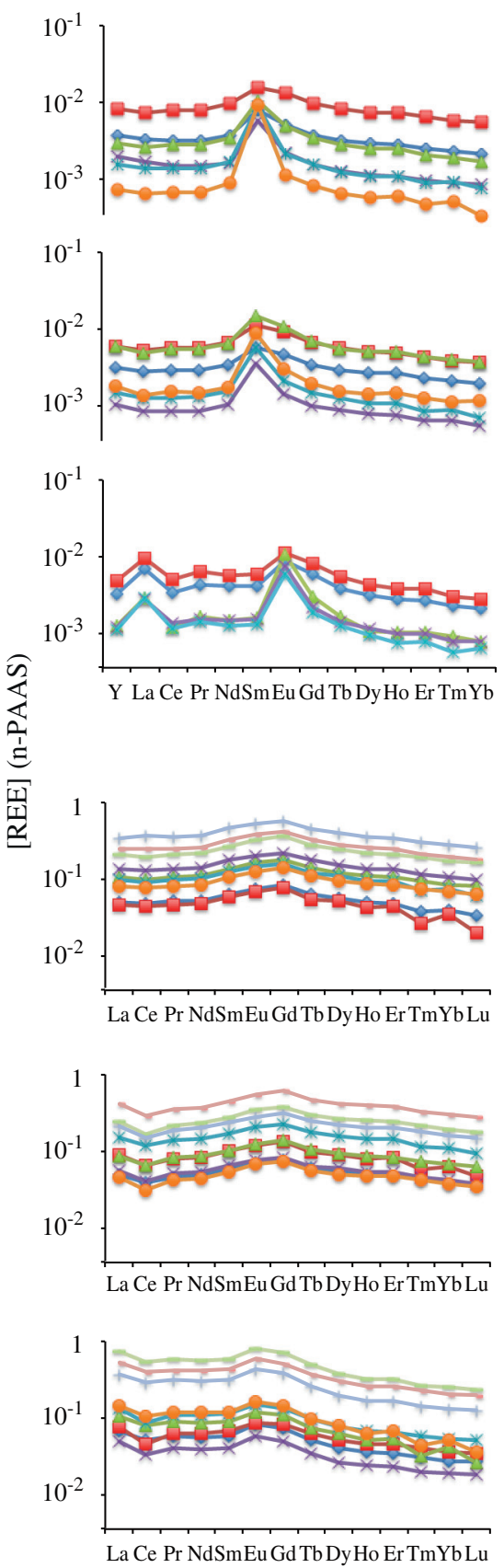
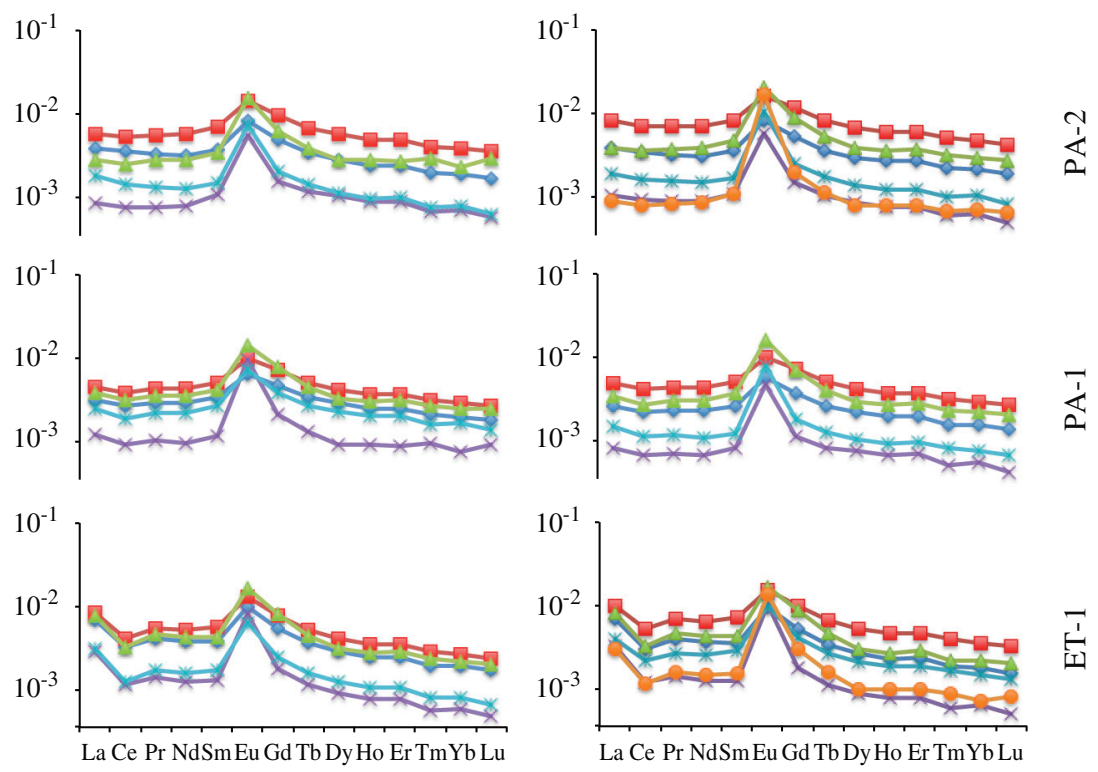

空
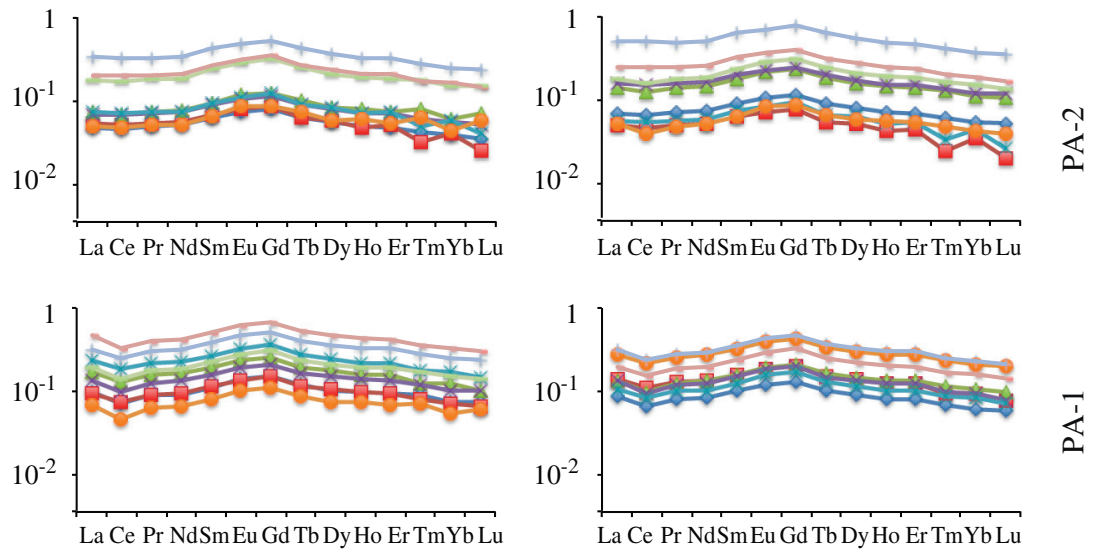

交

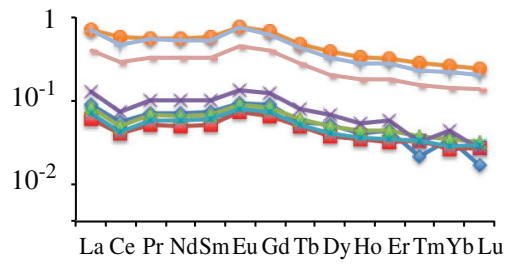

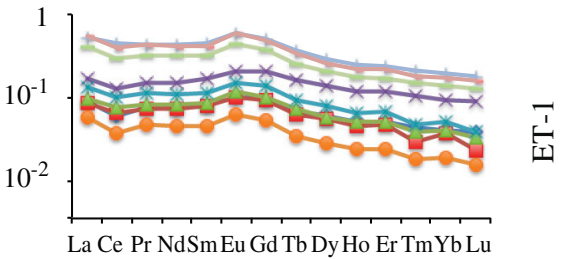

Fig. 4. Shale-normalised REE patterns of investigated grapevines grafted of studied rootstocks and grown on different soils.

growth stages progressively disappear during the last one, whereas HREE partitioning with respect to MREE continues to grow in the aerial parts. Ce anomalies were not found during these experiments, suggesting that Ce occurs as $\mathrm{Ce}^{3+}$ during metabolic processes in V. vinifera or that the organic complexes, which usually depress amplitudes of Ce anomaly, drive the REE speciation in plant fluids (Davranche et al., 2008) (Fig. 3).

\subsubsection{On-soil growth}

REE distributions in samples from grapevines grown on soil are reported in Supplementary information 4. Investigated samples are reported as leaves, roots (with different dimensions) and shoots. Samples are identified according to the three investigated rootstocks and growth stage achieved (being only rootstocks, only three different stages are considered). The $779 \mathrm{P}$ and $140 \mathrm{RU}$ rootstocks show higher REE contents than 1103 P, mainly in roots of plants growing on ET-1 and PA-2 soils. If rootstocks were grown on PA-1 soil this trend did not continue. This phenomenon suggests a possible rootstock effect on REE extraction from the labile soil fraction into the plant and could justify the different behaviours of root systems of selected rootstocks, especially during the early growth of the grapevine. Under this hypothesis, $779 \mathrm{P}$ and $140 \mathrm{RU}$ would enable a larger REE extraction from soils with higher REE contents 


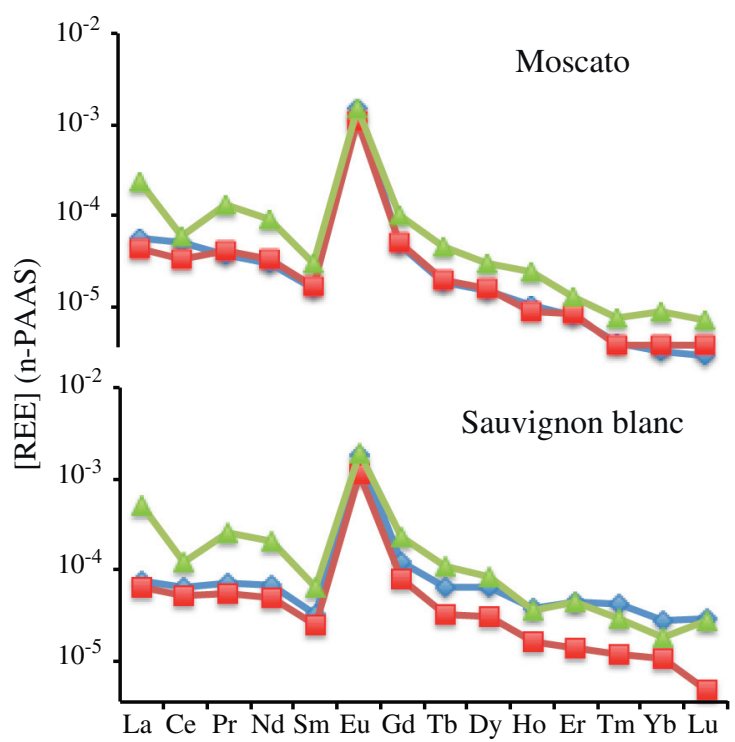

Fig. 5. Shale-normalised REE patterns of investigated grapevines on different studied soils. Symbols as in Fig. 1.

in labile fractions with respect to PA-2 soil. REE contents in Sauvignon blanc and Moscato d'Asti berries grafted onto 1103 were slightly lower than those found in other aerial plant parts (ranging from 8 to $46 \mu \mathrm{kg}^{-1}$ ), by about one order of magnitude with respect to leaves and about two-fold lower with respect to shoots.

Shale-normalised patterns were enriched in MREE and showed higher REE contents in roots, whereas both shoots and leaves showed Eu-positive anomalies (Fig. 4). These characteristics were not related to rootstocks and growth stages, and the recognition of positive La anomalies was related to the change in the substrate (Fig. 4). Both MREE enrichments and positive Eu anomalies in roots and aerial plant parts were not seen in plants grown off-soil. Therefore, these should represent effects related to interactions between $V$. vinifera and soils. Shale-normalised REE patterns recognised in Sauvignon blanc and Moscato d'Asti berries show similar shapes of those found in other aerial plant parts, always being characterised by significant positive Eu anomalies growing in patterns with LREE/HREE fractionations (Fig. 5).

\section{Discussion}

\subsection{Plant/soil relationships: roots}

In order to recognise whether a relationship exists between REE contents in plants and fractions extracted from soils, the distribution coefficients $\left(\mathrm{K}_{\mathrm{d}}\right)$ for different REEs were calculated with respect to both whole and labile soil fractions. Obtained $K_{d}$ values are about three orders of magnitude larger in roots with respect to aerial portions (Fig. 6). The sequences of $K_{d}$ values were quite similar for different employed rootstocks and soils. These are characterised by Ce-negative anomalies and flat features along the REE series if calculated with respect to labile soil fractions. In aerial parts of investigated plants, positive Eu anomalies were always recorded (Fig. 6).

Sequences of $K_{d}$ values along the REE series show significant tetrad effects in the third and fourth tetrads ( $\mathrm{Gd}-\mathrm{Ho}$ and $\mathrm{Er}-\mathrm{Lu}$, respectively). Their amplitudes are larger during the second and third growth stages (F2 and F3, respectively) where M-type tetrad effects are recognised in roots, whereas $\mathrm{W}$-type tetrad effects are found in shoots and leaves, especially for $K_{d}$ values calculated with respect to the labile soil fraction (Fig. 7). In the aerial plant organs, significant tetrad effects mainly occur during the first and third stages (W-Type TE if $t_{i} \leq 0.95$; M-type TE if $t_{i} \geq 1.05$; not significant tetrad effects if $0.95<t_{i}<1.05$ ) and are apparently not influenced by rootstock and soil types (Fig. 7).

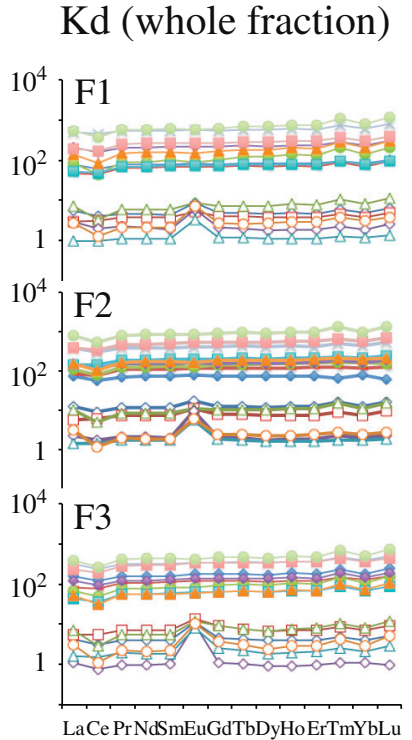

\section{$\mathrm{Kd}$ (labile fraction)}
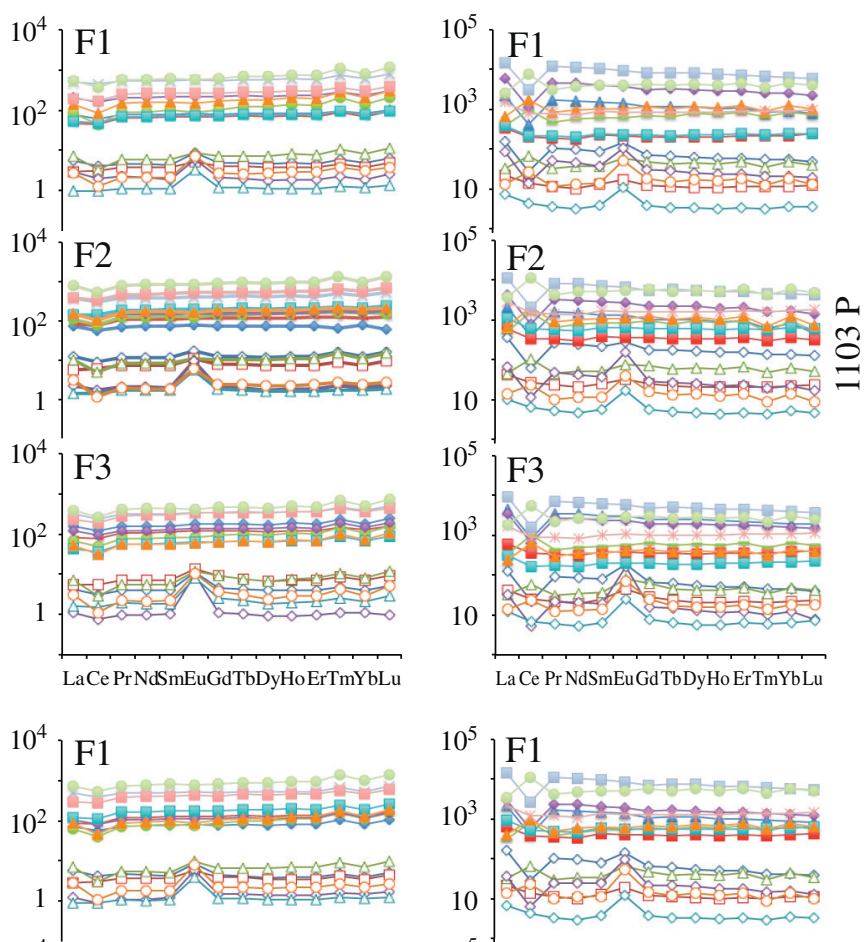

$10^{4}$

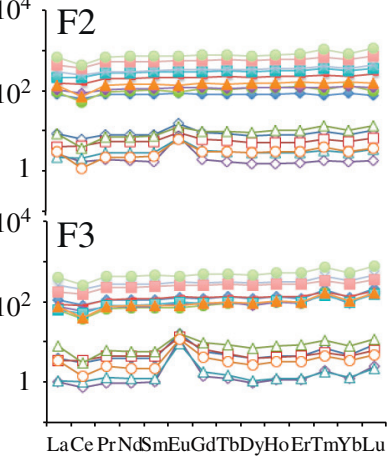

$10^{5} \mathrm{~F} 1$

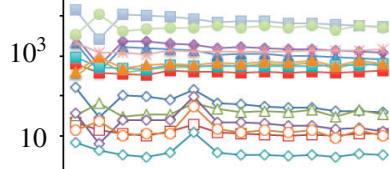

$10^{5}$

$10^{5} \mid \mathrm{F} 2$
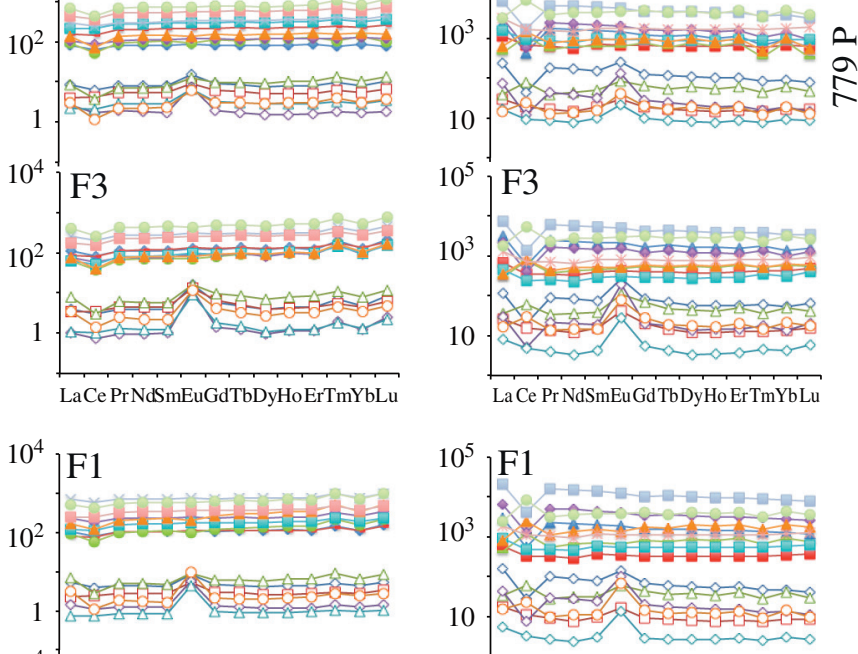

$10^{4}$

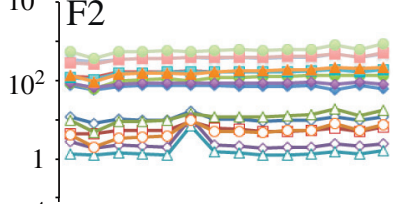

$10^{5}, \mathrm{~F} 1$

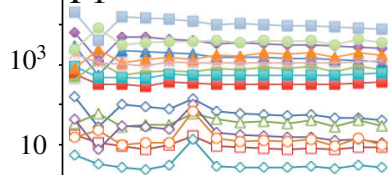

$10^{5} \mathrm{~F} 2$
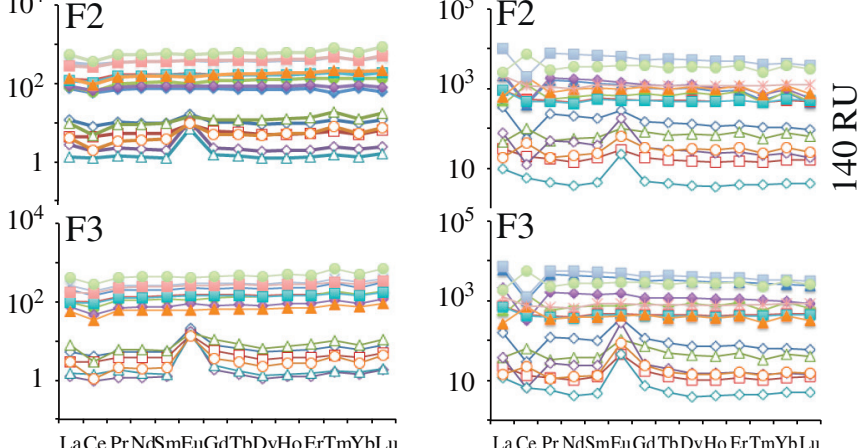

$10^{5} \mathrm{~F} 3$

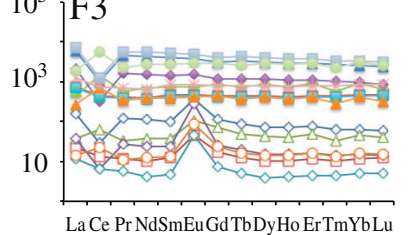

Fig. 6. Sequences of $K_{d}$ values for REE distribution in plant organs calculated at different growth stages (F1, F2, F3) with respect to the labile and the whole soil fractions for the employed rootstocks. Full symbols refer to root samples whereas open symbols represent aerial parts of Vitis vinifera. 

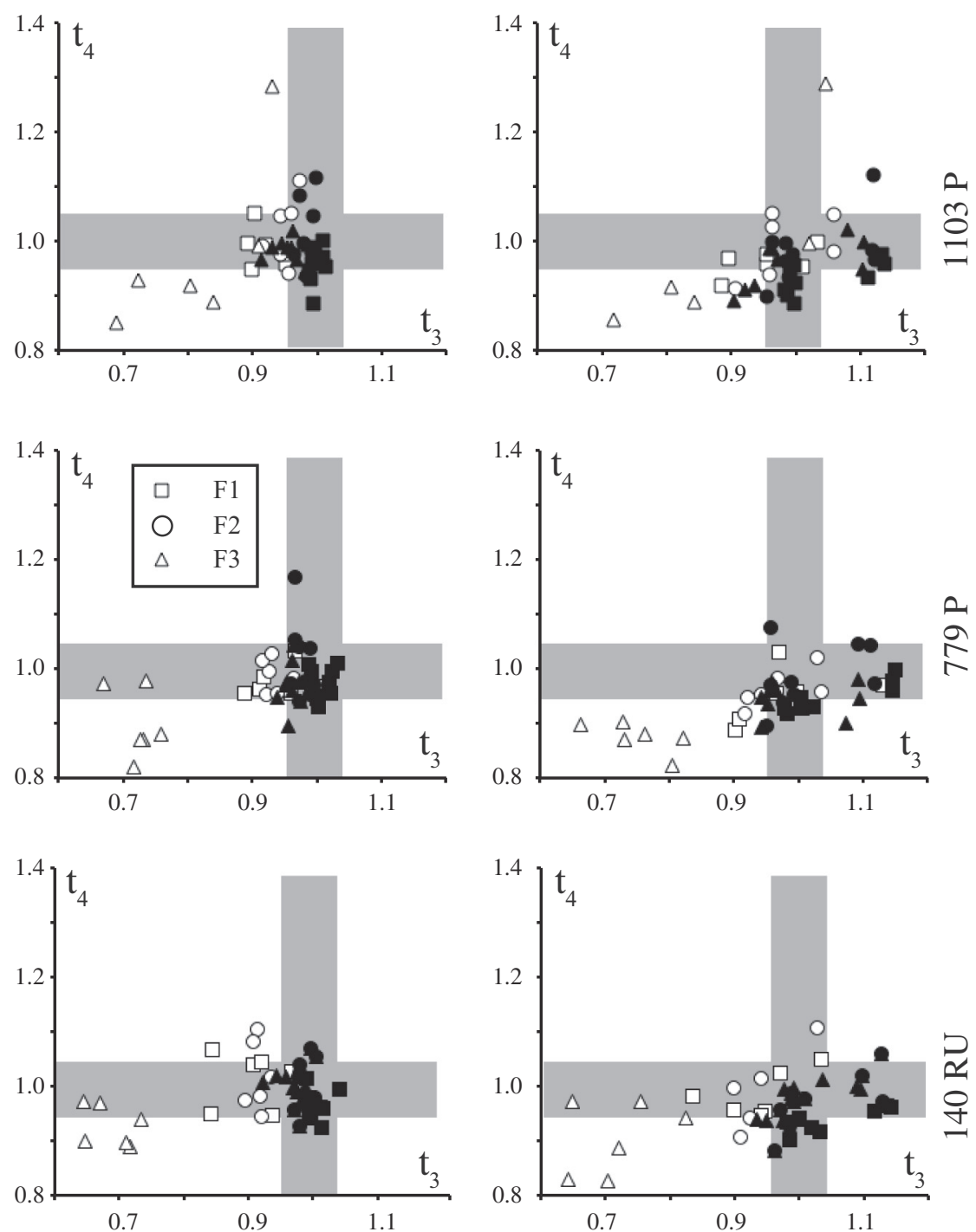

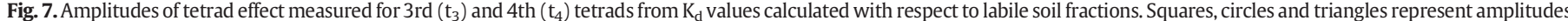

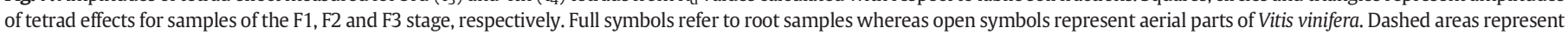
non-significant values.

According to the theory of Tetrad Effects, Masuda et al. (1987) indicated that W-type tetrad effects imply that REEs have been released from a coexisting solid and are in dissolved form. In our samples, similar features were associated with negative $\mathrm{Ce}$ anomalies $\left(\mathrm{Ce} / \mathrm{Ce}^{*}<1\right)$ in the aerial parts of investigated plants (Fig. 8), suggesting an oxidative Ce scavenging as insoluble $\mathrm{CeO}_{2}$ that is therefore subtracted from the dissolved pool (Bau and Koschinsky, 2009 and references therein). In contrast, the desultory recognition of M-type tetrad effects is limited to roots and associated with positive Ce anomalies therein (Fig. 8), suggesting that authigenic solids are deposed in the roots and the surfaces of these solids interact with dissolved REE allowing their surface complexation. Similar evidence has been shown in wheat roots (Ding et al., 2005, 2007; Lima E Cunha et al., 2012). The amplitudes of tetrad effects imply that both REE dissolved complexation in aerial parts and surface complexation onto authigenic solids in roots occur with an inner-sphere mechanism that can allow the observed $t_{3}$ and $t_{4}$ values (Bau, 1999; Kawabe, 1992; Masuda and Ikeuchi, 1979; Masuda et al., 1987; Monecke et al., 2002). Ding et al. (2006) suggested that phosphate deposition in wheat roots is responsible for M-type tetrad effects, whose amplitudes grow during plant growth similar to those in grapevines.

LREE partitioning observed in REE patterns in roots (Fig. 4) is a typical feature of several plants (Brioschi et al., 2012) and can be explained with the well-known reduced mobility of lighter REEs that are more surface-reactive than MREE and HREE (Byrne and Sholkovitz, 1996). At the same time, MREE accumulation in the finest roots agrees with the preferential accumulation of elements from $\mathrm{Sm}$ to Ho in the outer membranes during the early stages of cell growth (Dong et al., 2009; Gao et al., 2003). This process could be consistent with phosphate crystallisations in plants invoked by Tyler (2004) and Ding et al. (2005), since these compounds are usually enriched in MREE (Hannigan and Sholkovitz, 2001). In any case, the observed REE depletion in aerial parts of the grapevines and the REE fractionations in their roots is suggestive of a large-scale REE fractionation that could be an effect of REE interactions with biological membranes, as the Casparian strip occurring in the youngest roots, which can induce a geochemical decoupling of the element pair usually characterised by similar geochemical behaviour (Sparks et al., 2011).

\subsection{Aerial portions}

As previously mentioned, the REE migration from roots to the aerial portions in the studied plants involves REE depletions, positive Eu anomalies and associated W-type Tetrad Effects in aerial parts. Due to the presence of REE in the dissolved phase (Masuda et al., 1987), this evidence is suggestive of REE release from root tissues to the plant fluids 

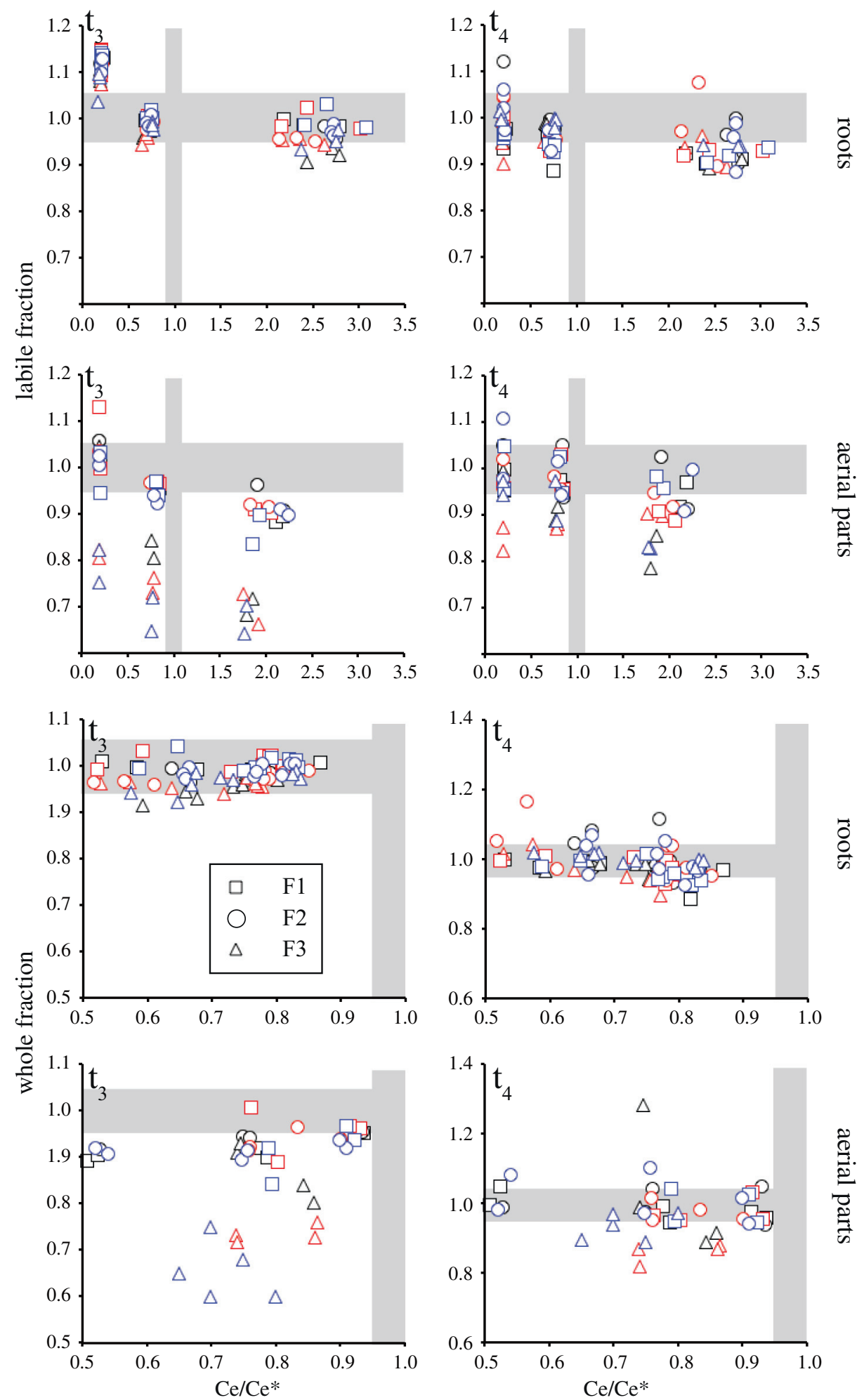

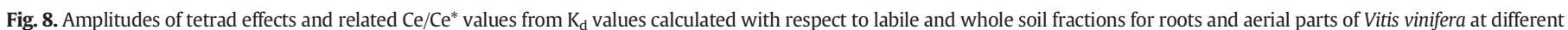
growth stages. Dashed areas represent non-significant values.

where Eu is preferentially complexed in xylem fluids. Ding et al. (2006) reported similar Eu anomalies in wheat leaves and explained them via an Eu-enriched phosphate crystallisation in several plant organs. However, this hypothesis does not seem convincing due to the lack of knowledge about these Eu-rich phosphates (Brioschi et al., 2012). On the contrary, the strong similarity between $\mathrm{Ca}^{2+}$ and $\mathrm{Eu}^{3+}$ makes it seem more reasonable that a Eu-Ca substitution can be induced during physiological processes occurring under favourable $\mathrm{Eu} / \mathrm{Ca}$ ratios in substrata (Zeng et al., 2003). Observed positive Eu anomalies also align with the greater stability of organic-REE complexes with respect to Ca complexes (Sastri et al., 2003), which can be explained by the stronger $\mathrm{Eu}^{3+}$ bond with proteins with respect to $\mathrm{Ca}^{2+}$ (Kruk et al., 2003). Evidences of promotion of biological activities played by $\mathrm{Eu}^{3+}$ are reported in Lathyrus sativus L. roots (Tian et al., 2003). Here, $\mathrm{Eu}^{3+}$ 
reduction to $\mathrm{Eu}^{2+}$ was demonstrated to influence the electron capture and transport of metals by binding proteins. In hydrothermal systems, $\mathrm{Eu}^{2+}$ has a lower affinity for sorption and its mobility is higher than $\mathrm{Eu}^{3+}$ and relative to its REE neighbours (Bau, 1991; Bau and Moller, 1992). Therefore, the possibility that observed positive Eu anomalies resulted from increased Eu mobility in the reduced $\mathrm{Eu}^{2+}$ form cannot be ruled out. Furthermore, positive Eu anomalies can result in enhanced Eu mobility and this process is related to the increasing nutrient transportation during metabolic processes in plants (Tian et al., 2003), which is corroborated by the recognition of positive Eu anomalies in the sap of xylem from several plants. This evidence suggests that a unique mechanism is responsible for transporting nutrients as well as trace elements and REE (Brioschi et al., 2012). This hypothesis agrees with the absence of Ce-positive anomalies in the studied samples, characteristic of REE migration as dissolved complexes rather than as a colloidal pool (Steinmann and Stille, 2008).

The role played during REE exploitation in agricultural practices carried out in China is justified by the capability of these elements to favour some metabolic processes leading to increases in plant productivity, by modifying, for example, stomatal openings and regulating transpiration and water depletion through plant leaves (Schroeder et al., 2001). Recent studies offer evidence for the ability of $\mathrm{Eu}^{3+}$ to intervene on the outward $\mathrm{K}^{+}$channels of Vicia guard cells and consequently regulating the cell water contents (Xue and Yang, 2009).

Similar binding sites have been demonstrated as powerful ligands favouring REE migrations in a wide range of physical-chemical conditions (Loges et al., 2012; Sonke and Salters, 2006; Xiong, 2011). Cations involved in migration processes through the xylem of grapevines are complexed with organic acids by means of polar bindings (Taiz and Zeiger, 2006) occurring between O-donor groups and $\mathrm{REE}^{3+}$, as demonstrated during hydroponic growth (Ding et al., 2006), mainly carboxyl or phosphate groups (Takahashi et al., 2010). According to Takahashi et al. (2010), REE binding through phosphate groups involves preferential HREE enrichment in the organic fraction and is preferred under low REE contents. In contrast, MREEs are enriched in organic compounds when higher REE concentrations occur and these elements are bound through carboxyl groups.

The behaviour of REE in berries (Fig. 5) is consistent with the few data about trace element distributions in these materials, resulting in REE being less concentrated in berries with respect to other aerial parts of grapevines (Bertoldi et al., 2009, 2011; Tyler, 2004). On the other hand, REE fractionations are different in berries, with LREE preferentially enriched with respect to other REEs. $K_{d}$ values calculated for berries are influenced by their studied variety, suggesting that some elemental fractionation can be induced by specific characteristics of the considered berries (Fig. 9). Only positive Eu anomalies remain to testify to a greater Eu mobility in plant fluids with respect to other REE. The preferential partitioning of MREE and Eu in berries and in the aerial portions of grapevines and the progressive LREE depletion from roots to berries strongly agrees with the REE behaviour in the presence of bacterial membranes, where MREEs are preferentially retained if the binding occurs through carboxyl O-donor groups (Takahashi et al., 2007, 2010).

\section{Conclusions}

The geochemical behaviour of REE in the V. vinifera/soil system is enhanced by features of the $K_{d}$ values along the element series calculated from roots and aerial portions with respect to the bioavailable soil fraction. $K_{d}$ values of LREE are slightly higher for LREE with respect to HREE in shoots, leaves and berries, and positive Eu anomalies are also found in the aerial portions. These features are consistent with preferential Eu complexation with respect to its neighbours via the same mechanism allowing $\mathrm{Ca}^{2+}$ mobilisation in xylem fluids, as indicated by comparing REE features in plants growing on-soil versus out-of-soil. Results shown in this research and those reported in other studies cannot give clear justifications of the enhanced Eu mobility with respect to its REE neighbours. Therefore, the observed Eu-positive anomalies could be related to the $\mathrm{Ca}-\mathrm{Eu}^{3+}$ substitution during metabolic processes and its transportation in binding proteins or they could result from an enhanced Eu mobility induced by $\mathrm{Eu}^{3+}$ reduction to $\mathrm{Eu}^{2+}$.

Negative Ce anomalies were observed both in roots and in aerial portions, which is in agreement with a reduced mobility of this element with respect to other LREE. Evidence of tetrad effects with W-type and M-type features in aerial portions and roots, respectively, corroborate suggestions that REE behaviour in aerial portions of $V$. vinifera is mainly partitioned in the dissolved phase, whereas these elements are preferentially scavenged in authigenic solids formed in roots. On the other hand, the possibility that M-type tetrad effects can be induced by interactions between REE and the Casparian strip in roots cannot be ruled out.

Although the shape of the $K_{d}$ paths is similar for different considered soils and grapevine varieties (i.e. positive Eu anomalies and HREE/LREE fractionations) some difference characteristics of soils and grapevine varieties can be recognised. This evidence suggests that REE distributions in $V$. vinifera evaluated according to an approach borrowed from geochemistry can provide suitable parameters allowing differentiation of berries coming from different substrates, and suggest that these parameters can help trace the origin of products derived from grapevines.
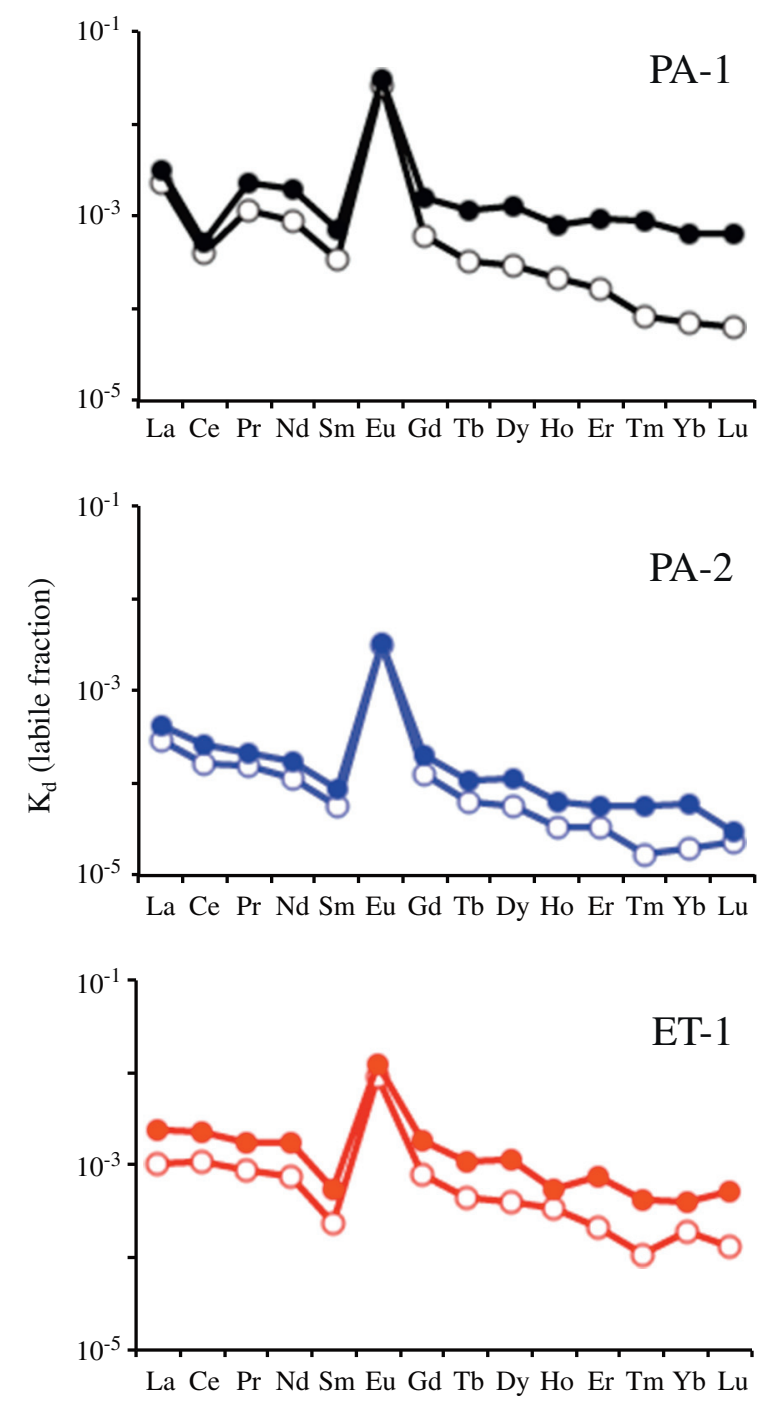

Fig. 9. Distribution coefficients of REE in the investigated grapevines on different soils Open symbol: Moscato; Full symbol: Sauvignon blanc. 


\section{Acknowledgements}

The authors are very grateful to two anonymous reviewers and to Charlotte Poschenrieder ( $\mathrm{AE}$ ) for their careful and dedicated job of critical revision of the first version of the manuscript. This paper reports scientific results belonging to the PhD project of $\mathrm{N}$. Tuzzolino.

\section{Appendix A. Supplementary data}

Supplementary data to this article can be found online at http://dx. doi.org/10.1016/j.scitotenv.2013.12.073.

\section{References}

Alibo DS, Nozaki Y. Rare earth elements in seawater: particle association, shalenormalization, and Ce oxidation. Geochim Cosmochim Acta 1999;63:363-72

Bau M. Rare-earth element mobility during hydrothermal and metamorphic fluid-rock interaction and the significance of the oxidation state of europium. Chem Geo 1991;93:219-30.

Bau M. Controls on the fractionation of isovalent trace elements in magmatic and aqueous systems: evidence from $\mathrm{Y} / \mathrm{Ho}, \mathrm{Zr} / \mathrm{Hf}$, and lanthanide tetrad effect. Contrib Mineral Petrol 1996;123:323-33.

Bau M. Scavenging of dissolved yttrium and rare earths by precipitating iron oxyhydroxide: experimental evidence for Ce oxidation, Y-Ho fractionation, and lanthanide tetrad effect. Geochim Cosmochim Acta 1999;63:67-77.

Bau M, Dulski P. Distribution of yttrium and rare-earth elements in the Penge and Kuruman iron-formations, Transvaal Supergroup, South Africa. Precambrian Res 1996;79:37-55.

Bau M, Koschinsky A. Oxidative scavenging of cerium on hydrous Fe oxide: evidence from the distribution of rare earth elements and yttrium between Fe oxides and Mn oxides in hydrogenetic ferromanganese crusts. Geochem J 2009;43:37-47.

Bau M, Moller P. Rare earth element fractionation in metamorphogenic hydrothermal calcite, magnesite and siderite. Mineral Petrol 1992;45:231-46.

Bavaresco L. Relationship between chlorosis occurrence and mineral composition of grapevine leaves and berries. Commun Soil Sci Plant Anal 1997;28:13-21.

Bertoldi D, Larcher R, Nicolini G, Bertamini M, Concheri G. Distribution of rare earth elements in Vitis vinifera L. ‘Chardonnay’ berries. Vitis J Grapevine Res 2009;48:49-51.

Bertoldi D, Larcher R, Bertamini M, Otto S, Concheri G, Nicolini G. Accumulation an distribution pattern of macro-and microelements and trace elements in Vitis vinifera L. cv. chardonnay berries. J Agric Food Chem 2011;59:7224-36.

Bertoldi D, Villegas TR, Larcher R, Santato A, Nicolini G. Arsenic present in the soil-vinewine chain in vineyards situated in an old mining area in Trentino, Italy. Environ Toxicol Chem 2013;32:773-9.

Brioschi L, Steinmann M, Lucot E, Pierret MC, Stille P, Prunier J, et al. Transfer of rare earth elements (REE) from natural soil to plant systems: implications for the environmental availability of anthropogenic REE. Plant and Soil 2012:1-21.

Busà T, Clochiatti R, Cristofolini R. The role of apatite fractionation and REE distribution in alkaline rocks from Mt. Etna, Sicily. Mineral Petrol 2002;74:95-114.

Byrne RH, Li B. Comparative complexation behavior of the rare earths. Geochim Cosmochim Acta 1995;59:4575-89.

Byrne RH, Sholkovitz ER. Marine chemistry and geochemistry of the lanthanides. In: Gschneidner Jr, Eyring LR, editors. Handbook of physics and chemistry of rare earths, Vol. 18. ; 1996. p. 497-593. [Chapter 158]

Chopin EIB, Marin B, Mkoungafoko R, Rigaux A, Hopgood MJ, Delannoy E, et al. Factors affecting distribution and mobility of trace elements $(\mathrm{Cu}, \mathrm{Pb}, \mathrm{Zn})$ in a perennia grapevine (Vitis vinifera L.) in the Champagne region of France. Environ Pollut 2008;156:1092-8

Cotton S. Lanthanide and actinide chemistry. Wiley; 2006263 [pp.].

d'Aquino L, Morgana M, Carboni MA, Staiano M, Antisari MV, Re M, et al. Effect of some rare earth elements on the growth and lanthanide accumulation in different Trichoderma strains. Soil Biol Biochem 2009;41:2406-13.

Darrah TH, Prutsman-Pfeiffer JJ, Poreda RJ, Ellen Campbell M, Hauschka PV, Hannigan RE. Incorporation of excess gadolinium into human bone from medical contrast agents. Metallomics 2009;1:479-88.

Davranche M, Pourret O, Gruau G, Dia A. Impact of humate complexation on the adsorption of REE onto Fe oxyhydroxide. J Colloid Interface Sci 2004;277:271-9.

Davranche M, Pourret O, Gruau G, Dia A, Le Coz-Bouhnik M. Adsorption of REE(III)humate complexes onto $\mathrm{MnO}_{2}$ : experimental evidence for cerium anomaly and lanthanide tetrad effect suppression. Geochim Cosmochim Acta 2005:69:4825-35.

Davranche M, Pourret O, Gruau G, Dia A, Jin D, Gaertner D. Competitive binding of REE to humic acid and manganese oxide: impact of reaction kinetics on development of cerium anomaly and REE adsorption. Chem Geol 2008;247:154-70.

Ding S, Liang T, Zhang C, Yan J, Zhang Z. Accumulation and fractionation of rare earth elements (REEs) in wheat: controlled by phosphate precipitation, cell wall absorption and solution complexation. J Exp Bot 2005;56:2765-75

Ding S, Liang T, Zhang C, Huang Z, Xie Y, Chen T. Fractionation mechanisms of rare earth elements (REEs) in hydroponic wheat: an application for metal accumulation by plants. Environ Sci Tech 2006;40:2686-91.

Ding S, Liang T, Yan J, Zhang Z, Huang Z, Xie Y. Fractionations of rare earth elements in plants and their conceptive model. Sci China C Life Sci 2007;50:47-55.
Dong S, Zhao Y, Liu H, Yang X, Wang K. Duality of effect of La3 + on mitochondrial permeability transition pore depending on the concentration. Biometals 2009;22:917-26.

Ehlers LJ, Luthy RG. Contaminant bioavailability in soil and sediment. Environ Sci Tech 2003;37:295A-302A

Ehlken S, Kirchner G. Environmental processes affecting plant root uptake of radioactive trace elements and variability of transfer factor data: a review. J Environ Radioact 2002;58:97-112.

Feng MH, Shan XQ Zhang S, Wen B. A comparison of the rhizosphere-based method with DTPA, EDTA, $\mathrm{CaCl}_{2}$, and $\mathrm{NaNO}_{3}$ extraction methods for prediction of bioavailability of metals in soil to barley. Environ Pollut 2005;137:231-40.

Gao Y, Zeng F, Yi A, Ping S, Jing L. Research of the entry of rare earth elements Eu3 + and La3 + into plant cell. Biol Trace Elem Res 2003;91:253-65.

Haley BA, Klinkhammer GP, McManus J. Rare earth elements in pore waters of marine sediments. Geochim Cosmochim Acta 2004;68:1265-79.

Hannigan RE, Sholkovitz ER. The development of middle rare earth element enrichments in freshwaters: weathering of phosphate minerals. Chem Geol 2001;175:495-508.

Hu Z, Richter H, Sparovek G, Schnug E. Physiological and biochemical effects of rare earth elements on plants and their agricultural significance: a review. J Plant Nutr 2004;27: 183-220.

Irber W. The lanthanide tetrad effect and its correlation with $\mathrm{K} / \mathrm{Rb}, \mathrm{Eu} / \mathrm{Eu} *, \mathrm{Sr} / \mathrm{Eu}, \mathrm{Y} / \mathrm{Ho}$, and $\mathrm{Zr} / \mathrm{Hf}$ of evolving peraluminous granite suites. Geochim Cosmochim Acta 1999;63: 489-508.

Kawabe I. Lanthanide tetrad effect in the Ln3 + ionic-radii and refined spin-pairing energy theory. Geochem J 1992;26:309-35.

Kruk J, Burda K, Jemioła-Rzemińska M, Strzałka K. The 33 kDa protein of photosystem II is a low-affinity calcium- and lanthanide-binding protein. Biochemistry 2003;42: 14862-7.

Liang T, Zhang S, Wang L, Kung HT, Wang Y, Hu A, et al. Environmental biogeochemical behaviors of rare earth elements in soil-plant systems. Environ Geochem Health 2005;27:301-11.

Liang T, Ding S, Song W, Chong Z, Zhang C, Li H. A review of fractionations of rare earth elements in plants. J Rare Earths 2008;26:7-15.

Lima e Cunha MC, Nardi LVS, Muller IF. Biogeochemistry of REE elements and tetrad effect in the soil-plant system: a study on volcanic rock covers in southernmost Brazil. An Acad Bras Cienc 2012;84:911-8.

Loges A, Wagner T, Barth M, Bau M, Göb S, Markl G. Negative Ce anomalies in Mn oxides: the role of $\mathrm{Ce}^{4+}$ mobility during water-mineral interaction. Geochim Cosmochim Acta 2012;86:296-317.

Masuda A, Ikeuchi Y. Lanthanide tetrad effect observed in marine environment. Geochem J 1979;13:19-22.

Masuda A, Kawakami O, Dohmoto Y, Takenaka T. Lanthanide tetrad effects in nature-two mutually opposite types, W and M. Geochem J 1987;21:119-24.

Michard G, Grimaud D, D'Amore F, Fancelli R. Influence of mobile ion concentrations on the chemical composition of geothermal waters in granitic areas. Example of hot springs from piemonte (Italy). Geophys J Roy Astron Soc 1989;18:729-41.

Möller P, Giese U. Determination of easily accessible metal fractions in rocks by batch leaching with acid cation-exchange resin. Chem Geol 1997;137:41-55.

Möller P, Morteani G, Dulski P. Anomalous gadolinium, cerium, and yttrium contents in the Adige and Isarco River waters and in the water of their tributaries (Provinces Trento and Bolzano/Bozen, NE Italy). Acta Hydrochim Hydrobiol 2003;31:225-39.

Monecke T, Kempe U, Monecke J, Sala M, Wolf D. Tetrad effect in rare earth element distribution patterns: a method of quantification with application to rock and mineral samples from granite-related rare metal deposits. Geochim Cosmochim Acta 2002;66:1185-96

Moriwaki H, Koide R, Yoshikawa R, Warabino Y, Yamamoto H. Adsorption of rare earth ions onto the cell walls of wild-type and lipoteichoic acid-defective strains of Bacillus subtilis. Appl Microbiol Biotechnol 2013;97:3721-8.

Ortiz-Villajos JAA, Navarro FJG, De Los Reyes CP, Gallego JAC, Martín-Consuegra SB, Ballesta RJ, et al. Geochemical influence of soil on leaf and grape (Vitis vinifera L. 'Cencibel') composition in la Mancha region (Spain). Vitis J Grapevine Res 2012;51: $111-8$.

Peppard DF, Mason GW, Lewey SA. Tetrad effect in the liquid-liquid extraction ordering of lanthanides(III). J Inorg Nucl Chem 1969;31:2271-2.

Raso M, Censi P, Saiano F. Simultaneous determinations of zirconium, hafnium, yttrium and lanthanides in seawater according to a co-precipitation technique onto iron-hydroxide. Talanta 2013;116:1085-90.

Rodushkin I, Ödman F, Holmström H. Multi-element analysis of wild berries from northern Sweden by ICP techniques. Sci Total Environ 1999;231:53-65.

Samczynski Z, Dybczyski RS, Polkowska-Motrenko H, Chajduk E, Pyszynska M, Danko B, et al. Two new reference materials based on tobacco leaves: certification for over a dozen of toxic and essential elements. The Scientific World Journal 2012. http://dx.doi.org/10.1100/2012/216380.

Sastri VS, Bünzli JC, Perumareddi JR, Rao VR, Rayudu GVS. Modern aspects of rare earths and their complexes. Amsterdam: Elsevier; 2003764 [p.]

Schijf J, Byrne RH. Stability constants for mono-and dioxalato-complexes of Y and the REE, potentially important species in groundwaters and surface freshwaters. Geochim Cosmochim Acta 2001;65:1037-46.

Schroeder JI, Allen GJ, Hugouvieux V, Kwak JM, Waner DGuard Cell Signal Transduct 2001;52:627-58.

Shannon R. Revised effective ionic radii and systematic studies of interatomic distances in halides and chalcogenides. Acta Crystallogr 1976;A32:751-67.

Sonke JE, Salters VJM. Lanthanide-humic substances complexation. I. Experimental evidence for a lanthanide contraction effect. Geochim Cosmochim Acta 2006;70: 1495-506.

Sparks JP, Chandra S, Derry LA, Parthasarathy MV, Daugherty CS, Griffin R. Subcellular localization of silicon and germanium in grass root and leaf tissues by SIMS: 
evidence for differential and active transport. Biogeochemistry 2011;104: 237-49.

Steinmann M, Stille P. Controls on transport and fractionation of the rare earth elements in stream water of a mixed basaltic-granitic catchment basin (Massif Central, France). Chem Geol 2008;254:1-18.

Taiz L, Zeiger E. Plant physiology. Sinauer; 2006.

Takahashi Y, Yoshida H, Sato N, Hama K, Yusa Y, Shimizu H. W- and M-type tetrad effects in REE patterns for water-rock systems in the Tono uranium deposit, central Japan. Chem Geol 2002;184:311-35.

Takahashi Y, Tada A, Shimizu H. Distribution pattern of rare earth ions between water and montmorillonite and its relation to the sorbed species of the ions. Anal Sci 2004;20: 1301-6.

Takahashi Y, Ch $\sqrt{ }$ ctellier X, Hattori KH, Kato K, Fortin D. Adsorption of rare earth elements onto bacterial cell walls and its implication for REE sorption onto natural microbial mats. Chem Geol 2005;219:53-67.

Takahashi Y, Hirata T, Shimizu H, Ozaki T, Fortin D. A rare earth element signature of bacteria in natural waters? Chem Geol 2007;244:569-83.

Takahashi Y, Yamamoto M, Yamamoto Y, Tanaka K. EXAFS study on the cause of enrichment of heavy REEs on bacterial cell surfaces. Geochim Cosmochim Acta 2010;74:5443-62.

Taylor SR, McLennan SM. The significance of the rare earths in geochemistry and cosmochemistry. In: Gschneidner Jr, Eyring LR, editors. Handbook of physics and chemistry of rare earths, vol. 11. ; 1988. p. 485-579. [Chapter 79].

Taylor SR, McLennan SM. The geochemical evolution of the continental crust. Rev Geophys 1995;33:241-65.
Tian HE, Gao YS, Li FM, Zeng F. Effects of europium ions (Eu3+) on the distribution and related biological activities of elements in Lathyrus sativus L. roots. Biol Trace Elem Res 2003;93:257-69.

Tyler G. Rare earth elements in soil and plant systems - a review. Plant and Soil 2004;267:191-206.

Viccaro M, Ferlito C, Cortesogno L, Cristofolini R, Gaggero L. Magma mixing during the 2001 event at Mount Etna (Italy): effects on the eruptive dynamics. J Volcanol Geotherm Res 2006;149:139-59.

Xin P, Shuang-Lin Z, Jun-Yao H, Li D. Influence of rare earth elements on metabolism and related enzyme activity and isozyme expression in Tetrastigma hemsleyanum cell suspension cultures. Biol Trace Elem Res 2013;152:82-90.

Xiong Y. Organic species of lanthanum in natural environments: implications to mobility of rare earth elements in low temperature environments. Appl Geochem 2011;26: 1130-7.

Xue S, Yang P. Effects of La3 + and Eu3 + on outward potassium channels in Vicia guard cells. Sci China, Ser B Chem 2009;52:1821-4.

Yamamoto Y, Takahashi Y, Shimizu H. Systematic change in relative stabilities of REE-humic complexes at various metal loading levels. Geochem J 2010;44 39-63.

Yang XC, Sachs F. Block of stretch-activated ion channels in Xenopus oocytes by gadolinium and calcium ions. Science 1989;243:1068-71.

Zeng F, Tian HE, Wang Z, An Y, Gao F, Zhang L, et al. Effect of rare earth element europium on amaranthin synthesis in Amarathus caudatus seedlings. Biol Trace Elem Res 2003;93: 271-82. 